\title{
Abbreviations of Journals and Serials Cited
}

Adv. Appl. Microbiol.

Adv. Chem. Ser.

Adv. Enzym.

Adv. Food Res.

Agric. Biol. Chem.

Agric. Eng.

Agric. Food Chem.

Agric. Hist.

Agric. Ital.

Agron. J.

Amer. Anthropol.

Amer. Chem. Soc. Symposium Ser.

Amer. Fruit Grower

Amer. Inst. Biol. Sci.
Advances in Applied Microbiology

Advances in Chemistry Series

Advances in Enzymology

Advances in Food Research

Agricultural and Biological Chemistry

Agricultural Engineering

Journal of Agricultural and Food Chemistry

Agricultural History

L'Agricoltura Italiana

Agronomy Journal

American Anthropologist

American Chemical Society. Symposium Series

American Fruit Grower

American Institute of Biological Sciences 
Amer. J. Bot.

Amer. J. Digest. Diseases

Amer. J. Enol. Vitic.

Amer. J. Physiol.

Amer. J. Psychol.

Amer. J. Pub. Health

Amer. Soc. Agric. Engin. Papers

Amer. Soc. Agron. Series

Amer. Soc. Brewing Chem. Proc.

Amer. Soc. Heat. Refrig. Air-Cond. Eng. J.

Amer. Wine Liquor J.

Anal. Chem.

Ann. Med. Exp. Fenn.

Ann. Phytopath.

Ann. Rev. Microbiol.

Annal. Technol. Agric.

Appl. Environ. Microbiology

Appl. Microbiol.

Arch. Biochem.

Arch. Biochem. Biophys.

Arch. Microbiol.

Arkansas State Hortic. Soc. Proc.

Assoc. Grower
American Journal of Botany

American Journal of Digestive Diseases

American Journal of Enology and Viticulture

The American Journal of Physiology

American Journal of Psychology

American Journal of Public Health

American Society of Agricultural Engineers.

Papers

American Society of Agronomy. Series

American Society of Brewing Chemists. Proceedings

American Society of Heating, Refrigerating and Air-Conditioning Engineers. Journal

American Wine and Liquor Journal

Analytical Chemistry

Annales Medicinae Experimentalis et Biologiae Fenniae

Annual Review of Phytopathology

Annual Review of Microbiology

Annales de Technologie Agricole

Applied and Environmental Microbiology

Applied Microbiology

Archives of Biochemistry

Archives of Biochemistry and Biophysics

Archives of Microbiology

Arkansas State Horticultural Society. Proceedings

Associated Grower 
Atti Accad. Ital. Vite Vino

Austral. Dried Fruits News

Austral. J. Agr. Res.

Austral. Wine Brew. Spirit Rev.

Bacteriol. Proc.

Better Crops Plant Food

Biotechnol. Bioeng.

Bol. Inst. Nac. Invest. Agron.

Book Club Calif. Quart. Newsletter

Bot. Gaz.

Bull. Off. Intern. Vin

Bull. Soc. Chim. France

Bull. Soc. Med. Friends Wine

C. R. Acad. Agric. France

Calif. Agric.

Calif. Agric. Exper. Stat. Bull.

Calif. Agric. Exper. Stat. Circ.

Calif. Agric. Exper. Stat. Leaflet

Calif. Agric. Exper. Stat. Exten. Serv. Man.

Calif. Agric. Exper. Stat. Report
Accademia Italiana della Vite e del Vino, Siena. Atti

Australian Dried Fruits News

Australian Journal of Agricultural Research

Australian Wine, Brewing and Spirit Review

Bacteriological Proceedings

Better Crops with Plant Food

Biotechnology and Bioengineering

Instituto Nacional de Investigaciones Agronomicas. Spain. Boletín

Book Club of California. Quarterly Newsletter

The Botanical Gazette

L'Office International de la Vigne et du Vin. Bulletin

Bulletin de la Société Chimique de France

Bulletin of the Society of Medical Friends of Wine

Académie d'Agriculture de France, Paris. Comptes Rendus des Séances

California Agriculture

California Agricultural Experiment Station. Bulletin

California Agricultural Experiment Station. Circular

California Agricultural Experiment Station. Leaflet

California Agricultural Experiment Station. Extension Service. Manual

California Agricultural Experiment Station. Report 
Calif. Agric. Exper. Stat. War Emerg. Leaflet

Calif. Agric. Exten. Serv. Bull.

Calif. Agric. Exten. Serv. Circ.

Calif. Agric. Exten. Serv. Leaflet

Calif. Agric. Exten. Serv. OSA

Calif. Agric. Exten. Serv. Pamphlet

Calif. Agric. Exten. Serv. Publ.

Calif. Citrograph

Calif. Coop. Exten. Serv. Bull.

Calif. Cultivator

Calif. Farmer

Calif. Fertilizer Conf. Proc.

Calif. Fruit News

Calif. Fruit Grape Grower

Calif. Grape Grower

Calif. Grower

Calif. J. Develop.

Calif. J. Technol.

Calif. Magazine Pacific

Calif. Monthly

Calif. Raisin Advisory Board Ann. Rept.
California Agricultural Experiment Station. War Emergency Leaflet

University of California. Agricultural Extension Service. Bulletin

University of California. Agricultural Extension Service. Circular

University of California. Agricultural Extension Service. Leaflet

University of California. Agricultural Extension Service. One.Sheet Answers

University of California. Agricultural Extension Service. Pamphlet

University of California. Agricultural Extension Service. Publication

California Citrograph

University of California. Cooperative Extension. Bulletin

California Cultivator

California Farmer

California Fertilizer Conference. Proceedings

California Fruit News

California Fruit and Grape Grower

California Grape Grower

California Grower

California Journal of Development

California Journal of Technology

California Magazine of the Pacific

California Monthly

California Raisin Advisory Board. Annual Report 
Calif. State Board Vitic. Commrs Bull.

Calif. State Dept. Agric. Bull.

Calif. Western States Grape Grower

Calif. Wine Rev.

Calif. Wine Spirit Rev.

Chem. Eng. News

CMI/AAB Descriptions Plant Viruses

Coll. of Agric. Report

Conaiss. Vigne Vin

CRC Critical Reviews Food Technol.

Current Anthro.

Develop. Ind. Microbiol.

Econ. Bot.

Food Agric. Organ. United Nations

Food Eng.

Food Ind.

Food Res.

Food Tech.

Fruit Prod. J.

Fruit Prod. J. Amer. Vinegar Ind.

Fruit Varieties Hort. Digest
California Board of State Viticultural Commissioners. Bulletin

California State Department of Agriculture Bulletin

California Western States Grape Grower

California Wine Revicw

California Wine and Spirits Review

Chemical and Engineering News

Commonwealth Mycological Institute and Association of Applied Biologists Descriptions of Plant Viruses

University of California. Report of the College of Agriculture

Connaissance de la Vigne et du Vin

Chemical Rubber Company, Cleveland. Critical Reviews in Food Technology

Current Anthropology

Developments in Industrial Microbiology

Economic Botany

Food and Agricultural Organization of the United Nations

Food Engineering

Food Industries Journal

Food Research

Food Technology

Fruit Products Journal and American Food Manufacturer

Fruit Products Journal and American Vinegar Industry

Fruit Varieties and Horticultural Digest 
Fruit Veg. Rev.

Giannini Fnd Agric. Econ. Mimeo. Rept.

Giannini Fnd Agric. Econ. Misc. Rept.

Giannini Fnd Agric. Econ. Paper

Giannini Fnd Agric. Econ. Res. Rept.

Hort. Sci.

Ice Cream Rev.

Idea Exper.

Ind. Bevande

Ind. Eng. Chem.

Inform. Fitopatol.

Inter. Con. Plant. Pathol. Muenchen

Intern. Congress Agric. Engin. Transactions

Intern. Enolog. Symp.

Intern. Inst. Agric.

Intell. Plant Dis. Month.

Intern. Jour. Syst. Bacteriol.

Inter. Symposium Quality Vintage

International Congress Applied Chemistry

J. Agric. Food Chem.
Fruit Vegetable Review

University of California. Giannini Foundation of Agricultural Economics. Mimeographed Report

University of California. Giannini Foundation of Agricultural Economics. Miscellaneous Report

University of California. Giannini Foundation of Agricultural Economics. Papers

University of California. Giannini Foundation of Agricultural Economics. Research Report

Horticultural Science

The Ice Cream Review

Idea and Experiment

Industrie delle Bevande

Industrial and Engineering Chemistry

Informatore Fitopatologico

International Conference of Plant Pathology, Muenchen. Abstracts of papers

International Congress of Agricultural Engineering. Transactions

International Denological Symposium

International Institute of Agriculture.

Bureau of Agricultural Intelligence and Plant Diseases. Monthly Bulletin

International Journal of Systematic Bacteriology

International Symposium on the Quality of the Vintage

International Congress of Pure and Applied Chemistry

Journal of Agricultural and Food Chemistry 
J. Agric. Res.

J. Amer. Chem. Soc.

J. Amer. Med. Assoc.

J. Amer. Oil Chem. Society

J. Amer. Soc. Hort. Sci.

J. Assoc. Off. Agric. Chem.

J. Assoc. Off. Anal. Chem.

J. Bacteriol.

J. Chem. Eng. Data

J. Chromatog.

J. Clin. Invest.

J. Econ. Entomol.

J. Farm Econ.

J. Food Sci.

J. Heredity

J. Hort. Sci.

J. Ind. Eng. Chem.

J. Inst. Brewing

J. Inst. Canadien Sci. Technol. Aliment.

J. Inst. Wood Sci.

J. Milk Food Technol.

J. Nematol.
Journal of Agricultural Research

Journal of the American Chemical Society

The Journal of the American Medical Association

Journal of the American Oil Chemists' Society

Journal of the American Society for Horticultural Science

Journal of the Association of Official Agricultural Chemists

Journal of the Association of Official Analytical Chemists

Journal of Bacteriology

Journal of Chemical and Engineering Data

Journal of Chromatography

Journal of Clinical Investigation

Journal of Economic Entomology

Journal of Farm Economics

Journal of Food Science

Journal of Heredity

Journal of Horticultural Science

The Journal of Industrial and Engineering Chemistry

Institute of Brewing, London. Journal

Journal de l'Institut Canadien de Science et Technologie Alimentaires

Institute of Wood Science. Journal

Journal of Milk and Food Technology

Journal of Nematology 
J. Nutr.

J. Organic Chem.

J. Sci. Food Agric.

Lab. Practice

Madras Agric. J.

MBAA Tech. Quarterly

Mem. Torrey Bot. Club

Mich. State Hort. Soc. Ann. Rept.

Mitt. Klosterneuburg

Mitt. (Klosterneuburg) Serie A

Mitt. (Klosterneuburg ) Serie B

Mycopath. Mycol. Appl.

New York's Food and Life Sci. Bull.

New York, State Agric. Exper. Stat. Res. Circ.

Off. Rept. Intern.

Cong. Vitic.

Pesticide Sci.

Phytochem.

Phytopath.

Plant Dis.

Plant Growth Regulator Bull.

Poultry Sci.

Proc. Calif. Plant and Soil Conf.
Journal of Nutrition

Journal of Organic Chemistry

Journal of the Science of Food and Agriculture

Laboratory Practice

The Madras Agricultural Journal

Master Brewers Association of America. Technical Quarterly

Memoirs of the Torrey Botanical Club

Michigan State Horticultural Society. Annual Report

Mitteilungen Klosterneuburg. Rebe und Wein. Obstbau und Fruechteverwertung

Mitteilungen (Klosterneuburg), Serie A: Rebe und Wein

Mitteilungen (Klosterneuburg), Serie B: Obst und Garten

Mycopathologica et Mycologia Applicata.

New York's Food and Life Sciences Bulletin

New York (State) Agricultural Experiment Station, Geneva. Research Circular

Official Report of the Session of the International Congress of Viticulture

Pesticide Science

Phytochemistry

Phytopathology

Plant Disease Reporter

Bulletin, Plant Growth Regulator

Poultry Science

California Plant and Soil Conference. Proceedings 
Proc. 1979 Table Grape Seminar

Proc. Amer. Phytopathologica Soc.

Proc. Amer. Soc. Enol.

Proc. Amer. Soc. Hort. Sci.

Proc. Ann. Meet. Plant Physiol.

Proc. Annual Calif. Fertilizer Conf.

Proc. Annual Wine Ind. Tech. Seminar

Proc. Biennial Intern. Codata Conf.

Proc. Calif. Acad. Sci.

Proc. Fruit Grower's Conv. Calif.

Proc. Helminth. Soc. Washington

Proc. Inst. Food Technol.

Proc. Intern. Conf. Virus Vector Perennial Hosts

Proc. Intern. Cong. Agric. Engin.

Proc. Intern. Plant Propagator's Soc.

Proc. Intern. Spec. Symp. Yeasts

Proc. Inter. Bot. Congr.

Proc. Pennsylvania Wine Conf.
1979 Table Grape Seminar. Proceedings

American Phytopathological Society. Proceedings

American Society of Enologists. Proceedings

American Society for Horticultural Science. Proceedings

American Society of Plant Physiologists. Proceedings

California Fertilizer Conference. Proceedings

Wine Industry Technical Seminar. Proceedings

International Codata Conference. Proceedings

California Academy of Sciences. Proceedings

California State Fruit Grower's Convention. Proceedings

Proceedings of the Helminthological Society of Washington

Institute of Food Technologists. Proceedings

International Conference on Virus and Vector on Perennial Hosts

International Congress of Agricultural Engineering. Proceedings

International Plant Propagator's Society. Proceedings

International Specialized Symposium on Yeasts. Proceedings

International Botanical Congress. Proceedings

Pennsylvania Wine Conference. Proceedings

Proc. Plant Propagators' Soc. Plant Propagators' Society. Proceedings 
Proc. Royal Australian Chem. Inst.

Proc. Sixth Annual Okanagan-Similkeen Grape Growers Forum

Proc. South African Society Enology and Viticulture

Proc. Statewide Conf. on Soil Tissue Testing

Proc. Symp. Grape Wine Centennial

Proc. Symp. Plant Phenolics Group

Proc. Symp. Tech. Sessions I and III CIGR

Proc. Western Plant Propagators Conf.

Proc. Western Weed Control Conf.

Proc. Wine Tech. Conf.

Proc. Intern. Congress Refrig.

Proc. Intern. Hort. Congress

Qual. Plant Mater. Veget.

Quart. Jour. Stud. Alcohol

Rev. Appl. Mycol.

Rev. Brasileira Tecnol.

Rev. Centro Ciencias Rurais

Rev. Horticole

Rev. Patol. Veget.
Proceedings of the Royal Australian Chemical Institute

Okanagan-Similkeen Grape Growers Forum. Proceedings

South African Society of Enology and Viticulture. Proceedings

Statewide Conference on Soil and Tissue Testing. Proceedings

University of California, Davis, Grape and Wine Centennial Symposium Proceedings

Symposium of the Plant Phenolics Group. Proceedings

Proceedings of the Symposium of the Technical Sections I and III of the Commission Internationale du Génie Rural

Western Plant Propagators Conference. Proceedings

Western Weed Control Conference. Proceedings

Wine Technology Conference. Proceedings

International Congress of Refrigeration. Proceedings

International Horticultural Conference. Proceedings

Qualitas Plantarum et Materiae Vegetabiles Quarterly Journal of Studies on Alcohol

Review of Applied Mycology

Revista Brasileira de Tecnologia

Revista do Centro de Ciencias Rurais

Revue Horticole

Revista de Investigaciones Agropecuarias. Series 5. Patologia Vegetal 
Rev. Vitic.

Sci. Monthly

Soil Sci.

S. Afr. J. Agric. Sci.

Suomen Kemist.

Synthetic. Commun.

Tech. Comm. of Intern. Soc. for Hort. Science

Trans. ASAE

Univ. Calif. Bull.

Univ. Calif. Div. Agric. Sci. Leaflet

Univ. Calif. Div. Agric. Sci. Priced Publ.

Univ. Calif. Div. Agric. Sci. Publ.

Univ. Calif. Div. Agric. Sci. Sale Publication

Univ. Calif. Div. Agric. Sci. Special Publ.

Univ. Calif. Div. Agric. Sci. Special Report

Univ. Calif. J. Agric.

Univ. Calif. Library Chapbook

Univ. Calif. Publ. Agric. Sci.

Univ. Calif. Public. Culture Soc.

Univ. Calif. Publ. Pharmacol.
Revue de Viticulture

Scientific Monthly

Soil Science

South African Journal of Agricultural Science

Suomen Kemistilehti

Synthetic Communications

Technical Communications of the International Society for Horticultural Science

American Society of Agricultural Engineers. Transactions

University of California Bulletin

University of California. Division of Agricultural Sciences. Leaflet

University of California. Division of Agricultural Sciences. Priced Publication

University of California. Division of Agricultural Sciences. Publication

University of California. Division of Agricultural Sciences. Sale Publication

University of California. Division of Agricultural Sciences. Special Publication

University of California. Division of Agricultural Sciences. Special Report

University of California. Journal of Agriculture

University of California, Davis. Library. Chapbook

University of California. Publications in Agricultural Sciences

University of California. Publications in Culture and Society

University of California. Publications in Pharmacology 
Univ. of Calif. Wine Tech. Conf.

Vinifera Wine Growers J.

Wallerstein Lab. Comm.

Washington State Hort. Assoc. Proc.

Weed Res.

West. Fruit Grower

West. Medicine

Wine Rev.
Wine Technology Conference, University of California, College of Agriculture.

Proceedings

Vinifera Wine Growers Journal

Wallerstein Laboratories, New York.

Wallerstein Laboratories Communications

Washington State Horticultural Association. Proceedings

Weed Research

Western Fruit Grower

The Western Journal of Medicine

The Wine Review 